\title{
ANALISIS SWOT STRATEGI PEMASARAN ASURANSI JIWA AJB BUMI PUTERA 1912
}

\author{
Sri Handayani \\ Program Studi Manajemen \\ Dosen Fakultas Ekonomi Universitas Dehasen Bengkulu
}

\begin{abstract}
ABSTRAK
Sri Handayani; Dewasa ini pertumbuhan usaha dalam sektor asuransi jiwa di Indonesia terus membaik, tapi belajar dari pengalaman sektor perbankan, perlu diteliti apakah eksistensi pelaku usaha milik nasional dalam sektor asuransi jiwa menjadi terdesak dan kehilangan pangsa pasar didalam negeri berhadapan dengan pelaku usaha yang berasal dari luar negeri yang berhasil memenangkan kepercayaan yang lebih besar dari pembeli jasa perlindungan asuransi. Penelitian ini bertujuan untuk menganalisa kekuatan dan kelemahan dalam menghadapi kesempatan dan ancaman dari strategi pemasaran asuransi jiwa AJB Bumiputera 1912 Bengkulu. Sampel dalam penelitian ini adalah asumsi strategi yang efektif memaksimalkan kekuatan dan kesempatan perusahaan dan meminimalisir kelemahan dan ancaman. Metode yang digunakan adalah analisis SWOT. Hasil penelitian ini menunjukkan bahwa AJB Bumiputera 1912 Bengkulu strategi yang bisa diterapkan adalah strategi integrasi horizontal, efisiensi biaya serta pemanfaatan tehnologi tinggi untuk sistem pembayaran dan sistem pemesanan produk asuransi , semua ini harus diarahkan untuk kepuasan konsumen.
\end{abstract}

\section{ABSTRACT}

Sri Handayani ; Today's business growth in the life insurance sector in Indonesia continues to improve, but to learn from the experience of the banking sector, it should be examined whether the existence of the businesses owned nationwide in the life insurance sector becomes desperate and lost market share in the country to deal with businesses that come from overseas managed to win greater trust from the buyers insurance protection services. This study aimed to analyze the strengths and weaknesses in the face of opportunities and threats of life insurance marketing strategy AJB Bumiputera 1912 Bengkulu. The sample in this study is the assumption of an effective strategy to maximize the strengths and minimize the weaknesses of the company and the opportunities and threats. The method used is the SWOT analysis. These results indicate that the AJB Bumiputera 1912 Bengkulu workable strategy is a strategy of horizontal integration, cost efficiency and the use of high technology to the payment system and insurance product ordering system, all of this should be directed to customer satisfaction.

\section{Keyword: SWOT Analysis, Marketing Strategy}

\section{PENDAHULUAN}

Strategi Pemasaran Produk Asuransi merupakan suatu bentuk aktivitas penjualan yang saat ini masih banyak diminati masyarakat. Arti sebenarnya dari asuransi adalah perlindungan nilai ekonomi seseorang atau kumpulan (corporate). Arti lain dari Asuransi juga bisa diartikan, penggantian sebagian bahkan keseluruhan akibat adanya suatu kerugian baik itu jiwa atau material yang dialami oleh individu atau kumpulan.

Strategi Pemasaran Produk Asuransi adalah sama dengan anda menawarkan produk yang bersifat maya atau tidak tampak, seperti : produk dana pasar uang, produk Obligasi dan produk Saham, mengapa demikian?. Karena asset tidak berwujud ini sama-sama memiliki kekurangan yakni besaran nilai uang yang tidak bisa diprediksi secara konsisten dimasa yang akan datang. Inilah yang menyebabkan anda tidak bisa asal-asalan dalam melakukan penjualan produk-produk diatas termasuk produk Asuransi. 
Perusahaan perlu mengenali kekuatan dan kelemahan perusahaan dalam persaingan, hal ini akan sangat membantu dalam mengendalikan diri, serta memanfaatkan setiap peluang yang ada. Dimana strategi pemasaran merupakan upaya mencari posisi pemasaran yang menguntungkan dalam suatu industri atau arena fundamental persaingan berlangsung. Pemasaran di suatu perusahaan, selain bertindak dinamis juga harus selalu menerapkan prinsip-prinsip yang unggul dan perusahaan harus meninggalkan kebiasaan-kebiasaan lama yang sudah tidak berlaku serta terus menerus melakukan inovasi. Karena sekarang bukanlah jaman dimana produsen memaksa kehendak terhadap konsumen, melainkan sebaliknya konsumen memaksa kehendaknya terhadap produsen.

Asuransi jiwa Bersama Bumiputera 1912 adalah perusahaan asuransi jiwa nasional milik bangsa Indonesia yang pertama dan tertua dan berhasil menguasai pasar tradisional dan menyediakan produk-produk pelayanan yang diinginkan, namun demikian situasi pasar saat ini berubah, pasar semakin beragam dan sangat kompetitif, karena situasi pasar saat ini tidak hanya terdiri dari satu segmen saja, melainkan dari semua tingkatan, segmentasi pasar memerlukan yang berbeda-beda dan dapat dikelompokkan menjadi kelompok standar, kumpulan dan eksekutif. Dengan demikian AJB Bumi Putera 1912 harus tanggap untuk menghadapi tantangan dan peluang baru untuk tetap menjadi nomor satu AJB Bumi Putera 1912 harus lebih agresif dari persaingan bisnis asuransi jiwa yang semakin tajam . Dengan latar belakang inilah penulis tertarik untuk meneliti bagaimana strategi pemasaran produk asuransi jiwa dengan analisa SWOT, dengan mengambil judul "Analisis SWOT Strategi Pemasaran AJB BUMI PUTERA 1912 .

\section{Landasan Teori Analisis SWOT}

Analisis SWOT merupakan cara yang sistematik didalam melakukan analisis terhadap wujud ancaman kesempatan agar dapat membedakan keadaan lingkungan yang akan datang sehingga dapat ditemukan masalah yang ada. Dari analisis SWOT, perusahaan dapat menentukan strategi efektif yang sejauh mungkin memanfaatkan kesempatan yang berlandaskan pada kekuatan yang dimiliki perusahaan, mengatasi ancaman yang akan datang dari luar, serta mengatasi kelemahan yang ada.

Analisis SWOT atau di Indonesiakan menjadi KEKEPAN( Kekuatan-KelemahanKesempatan-Ancaman) sudah sangat umum dikenal dan mudah untuk dilakukan. Proses manajemen strategi adalah sebuah proses delapan langkah yang mencakup perencanaan strategi, pelaksanaan atau penerapan dan evaluasi. Analisis adalah suatu kegiatan untuk memahami seluruh informasi yang terdapat pada suatu kasus, mengetahui isu apa yang sedang terjadi, dan memutuskan tindakan apa yang harus segera dilakukan untuk memecahkan masalah.

Menurut Anonym, (2009) Analisis SWOT adalah Identifikasi berbagai faktor secara sistematik untuk merumuskan strategi sebuah perusahaan dan organisasi internal maupun eksternal. Analisa ini didasarkan pada logika yang dapat memaksimalkan kekuatan (Strenght) dan peluang (Opportunities) dan namun secara bersamaan dapat meminimalkan kelemahan (Weaknesses) dan ancaman (Threats).

Menurut Rangkuti, Freddy (1997) Analisis SWOT adalah suatu identifikasi sistematis dari faktor-faktor dan strategi yang memperlihatkan perpaduan terbaik diantara mereka. Analisis ini bertolak dari asumsi bahwa strategi yang efektif memaksimalkan kekuatan dan kesempatan perusahaan dan meminimalisir kelemahan dan ancaman,pada penerapan yang akurat, asumsi sederhana ini mempunyai implikasi kuat terhadap desain dari sebuah strategi yang berhasil.

\section{Strategi Pemasaran}

Menurut Philip Kotler (1997), Pemasaran adalah suatu proses dan manajerial dengan mana seseorang atau kelompok memperoleh apa yang mereka butuhkan dan inginkan melalui 
penciptaan dan pertukaran produk dan nilai. Jadi pemasar adalah seseorang untuk merancang dan merencanakan dalam menentukan harga, mempromosikan dan mendistribusikan barangbarang untuk memuaskan para konsumen.

Didalam melakukan analisis terhadap pesaing, suatu perusahaan harus meneliti secara detail kekuatan-kekuatan mana yang dimiliki oleh pesaing yang telah lama memasuki arena persaingan maupun pendatang baru, kemudian bahwa aspek yang sangat penting dalam perumusan strategi adalah analisis pesaing yang handal dan akan menentukan posisi (positioning) suatu usaha, sehingga memiliki keunggulan diferensial dari pesaing.

Menurut Tjiptono, Fandy (1997) Strategi Pemasaran adalah : " Sebagai alat fundamental yang direncanakan untuk mencapai tujuan perusahaan dengan mengembangkan keunggulan bersaing yang berkesinambungan pemasaran yang digunakan untuk melayani pasar sasaran tersebut. Strategi pemasaran terdiri atas 5 elemen yang saling berkait, kelima elemen tersebut adalah:

1. Pemilihan Pasar, Yaitu pasar yang akan dilayani, pemilihan pasar dimulai dengan melakukan segmentasi pasar dan kemudian memilih pasar sasaran yang paling memungkinkan untuk dilayani oleh perusahaan.

2. Perencanaan Produk, meliputi produk spesifik yang dijual pembentukan lini produk dan desain penawaran individual pada masing-masing lini, produk itu sendiri menawarkan manfaat total yang dapat diperoleh pelanggan dengan melakukan pembelian .

3. Penetapan Harga, yaitu menentukan harga yang dapat mencerminkan nilai kuantitatif dari produk kepada pelanggan.

4. Sistem distribusi, yaitu saluran wholesale dan retail yang dilalui produk hingga mencapai konsumen akhir yang membeli dan menggunakkannya.

5. Komunikasi pemasaran(Promosi), yang meliputi periklanan, Personal selling, dan publik relation.

Dalam merumuskan strategi pemasaran dibutuhkan pendekatan-pendekatan analisis kemudian dalam mengembangkan strategi bersaing, langkah pertama adalah melakukan analisis bersaing yang meliputi faktor eksternal dan internal. Faktor Eksternal yaitu : analiisis pelangan pesaing, industri dan lingkungan. Sedangkan faktor untuk analisis internal yaitu : analisis performance, analisis strategi, strategi prioritas, cost portopolio, financial resources dan analisis kekuatan dan kelemahan.

\section{HASIL DAN PEMBAHASAN}

AJB Bumiputera 1912 adalah perusahaan asuransi jiwa pertama dan tertua di Indonesia Didirikan di Magelang, Jawa Tengah pada tanggal 12 Februari 1912 dengan nama Onderlinge Levensverzekering PGHB. Dari tempat asalnya , Magelang AJB Bumi Putera 1912 pindah ke Yogyakarta pada tahun 1921 kemudian tahun 1958 pindah ke Jakarta yang beralamat di Wisma Bumi Putera, lt 17-21 Jl. Jend Sudirman Kav 7,5 Jakarta 12910 , hingga saat ini merupakan pangkalan utama mengendalikan perusahaan yang jaringannya tersebar diseluruh penjuru tanah air dan melakukan hubungan internasional dengan rekan-rekan dinegara lain. AJB Bumi Putera 1912 memiliki sekitar 2.900 karyawan dan 23.000 agen yang tersebar di 645 kantor yang strategis terdapat diseluruh tanah air yang melayani lebih dari 5 juta pemegang polis dan masyarakat umum.

Salah satu kekuatan Bumi Putera adalah kepemilikan dan bentuk perusahaan yang unik , di mana Bumi Putera adalah satu-satunya perusahaan di Indonesia yanh berbentuk "Mutual" atau "usaha Bersama" artinya pemilik perusahaan adalah para pemegang polis , bukan pemegang saham . Hal ini dikarenakan premi yang diberikan kepada perusahaan sekaligus dianggap sebagai modal. Badan Perwakilan Anggota yang merupakan perwakilan para pemegang polis ikut serta menentukan garis-garis besar haluan perusahaan, memilih dan mengangkat direksi, dan ikut serta mengawasi jalannya perusahaan. Pengurus juga mengendalikan kelompok usaha Bumiputera yang terdiri dari anak-anak perusahaan, asosiasi dan penyertaan, antara lain: PT.Bumida Bumiputera 1967, PT. Bank Bumiputera dan lain-lain.

Perkembangan tehnologi dan informasi diera globalisasi saat ini sangat pesat dan 
sangat berpengaruh terhadap segala aspek kehidupan, sebagai langkah antisipasi pengelolaan operasional perusahaan juga harus dapat menyesuaikan dengan perubahan keadaan yang terjadi, maka orientasi operasional perusahaan difokuskan pada "Market Driven" yang artinya seluruh gerakan pengelolaan organisasi perusahaan pemasaran harus berorientasi pada kebutuhan dan keinginan pasar sesuai dengan target marketnya.

Analisis SWOT Strategi Pemasaran AJB Bumiputera 1912

1. Faktor Internal (IFAS)

Matrik IFAS digunakan untuk mengetahui seberapa besar peranan dari Faktor-faktor internal yang terdapat pada perusahaan. Matrik IFAS disususn berdasarkan hasil identifikasi dari kondisi lingkungan internal perusahaan berupa kekuatan dan kelemahan yang dimiliki AJB Bumiputera 1912 dalam memasarkan produk asuransi a. Kekuatan ( Strength)

Kekuatan menggambarkan hal yang dimiliki perusahaan dan dapat memberikan keunggulan kompetitif bagi perusahaan itu sendiri . Berdasarkan analisis yang telah diperoleh beberapa kekuatan yang dimiliki AJB Bumi Putera 1912 dalam memasarkan produk asuransi. Kekuatan tersebut antara lain :

1. Paling Tua Di Indonesia

AJB Bumiputera 1912 adalah perusahaan asuransi jiwa nasional pertama dan tertua di Indonesia. Didirikan di Magelang, Jawa Tengah tanggal 12 Februari 1912 dengan nama Onderlinge Levensuerzekering PGHB. Berarti Empat tahun setelah berdirinya "Boedi Utomo" sebuah gerakan nasional yang merupakan sumber inspirasi para pelopor AJB Bumiputera 1912 dan perusahaan ini merupakan satu-satunya perusahaan ini pun berbentuk usaha bersama (Mutual) di Indonesia.

2. Telah Terbukti memberikan peranan penting

Selama bertahun-tahun AJB Bumiputera 1912 merupakan asuransi jiwa terbesar di Indonesia yang mempunyai sekitar lebih dari 5 juta pemegang polis dan menyediakan produk dan pelayanan sesuai dengan kebutuhan yang diinginkan. Ini merupakan bukti bahwa asuransi telah memberikan peranan penting bagi kehidupan masyarakat diberbagai lapisan serta dalam pembangunan bangsa serta peningkatan kesejahteraan masyarakat melalui jasa asuransi jiwa.

3. Dapat dipercaya dan dapat diandalkan

AJB Bumiputera 1912 sejak lama sudah mendapat kepercayaan dari masyarakat sehingga bisa dianserta paling disegani oleh perusahaan asuransi lain sebab kualitaas dan kualtitas organisasinya mantap dan profesional dalam menguasai pasar asuransi, keterampilan dalam menyajikan dan keterampilan dalam menjalankan tugasnya di masyarakat.

4. Terbukti sebagai pather ideal bagi organisasi / indivudual

Sampai sekarang AJB Bumiputera 1912 sudah banyak dikenal oleh masyarakat dan merupakan pather yang ideal karena dapat memberikan proteksi sesuai dengan kebutuhan yang diinginkan, terbukti dengan pertambahan portopolio setiap tahun meningkat $25 \%$ dari portopolio awal.

5. Telah memasyarakat sampai kekota-kota kecil

Asuransi jiwa telah memasyarakat diberbagai kota baik itu dikota-kota besar maupun kota-kota kecil terbukti dengan tersebarnya 645 kantor yang strategis dan terdapat diseluruh Indonesia.

6. Sistem Manajemen yang baik,

Perkembangan tehnologi dan informasi diera globalisasi saat ini sangat pesat dan berpengaruh terhadap segala aspek kehidupan, sebagai langkah antisipasi pengelolaan operasional perusahaan juga harus dapat menyesuaiakan dengan perubahan keadaan yang terjadi , maka orintasi operasional perusahaan AJB Bumiputera 1912 difokuskan pada "Market Driven" yang artinya seluruh gerakan pengelolaan organisasi pemasaran harus berorientasi pada kebutuhan dan keinginan pasar saesuai dengan target marketnya. Untuk mencapai 
kesimbangan pelayanan prima terhadap para pemegang polis, Bumiputera selalu mengadakan pelatihan, pendidikan serta peningkatn profesional bagi karyawan-karyawatinya dengan kompensasi yang sebanding dengan prestasi, sekaligus memperbaiki kesejahteraannya.

7. Pembayaran klaim yang baik

Bagi AJB Bumiputera 1912 nasabah adalah pelanggan, dengan mempunyai kedudukan adalah raja dan dilayani secara baik, sehingga dapat memuaskan nasabah apabila puas dengan pelayanan, maka akan terjadi pembelian ulang dari produk dan nasabah mendapatkan haknya dengan baik seperti :

- Pelayanan pembayaran penutupan

- Pelayanan pembayaran konservasi

- Pelayanan pembayaran klaim habis kontrak

- Pelayanan pembayaran klaim meninggal

- Pelayanan pembayaran klaim penebusan

- Pelayanan pinjaman polis.

Setelah memperoleh bobot dan rating maka dapat diperoleh skor, dengan cara mengalikan bobot dengan rating,dapat dilihat pada tabel dibawah ini :

\begin{tabular}{|l|l|c|c|c|}
\hline No & \multicolumn{1}{|c|}{ KEKUATAN } & BOBOT & RATING & SKOR \\
\hline 1 & Paling tua di Indonesia & 0,15 & 4 & 0,60 \\
\hline 2 & $\begin{array}{l}\text { Telah terbukti memberikan peranan } \\
\text { penting }\end{array}$ & 0,10 & 4 & 0,40 \\
\hline 3 & \begin{tabular}{l} 
Dapat dipercaya dan dapat diandalkan \\
\hline 4
\end{tabular} & 0,10 & 3 & 0,30 \\
\hline $\begin{array}{l}\text { Terbukti sebagai pather ideal bagi } \\
\text { organisasi/individual }\end{array}$ & 0,05 & 2 & 0,10 \\
\hline 5 & $\begin{array}{l}\text { Telah memasyarakat sampai ke kota- } \\
\text { kota kecil }\end{array}$ & 0,075 & 2 & 0,15 \\
\hline 6 & Sistem manajemen yang baik & 0,05 & 1 & 0,05 \\
\hline 7 & Pembayaran klaim yang baik & 0,10 & 3 & 0,30 \\
\hline & Jumlah & $\mathbf{0 , 6 2 5}$ & 19 & 19,00 \\
\hline
\end{tabular}

Dari hasil perhitungan diatas dapat diketahui bahwa pernyataan yang behubungan dengan kekuatan (streanghts) dapat disimpulkan bahwa keseluruhan pernyataan itu merupakan kekuatan bagi AJB Bumiputera 1912.

a. Kelemahan (Weaknesess)

Kelemahan menggambarkan hal yang tidak dimiliki perusahaan tetapi perusahaan lain memilikinya. Berdasarkan analisis yang telah dilakukan maka diperoleh beberapa kelemahan yang ada pada AJB Bumiputera 1912 dalam memasarkan produk asuransi :

1. Sistem training yang kurang dikembangkan dari tehnik asuransi kepada tehnik marketing dan sales bagi setiap petugas dinas luar, supervisor dan pimpinan rayon sebagai ujung tombak perusahaan.

Perusahaan ini memiliki sekitar 2.900 karyawan dan 23.000 agen luar yang mana AJB Bumiputera 1912 berusaha untuk meningkatkan sumberdaya manusia dengan mengadakan training dan latihan-latihan namun training yang diadakan kurang dapat dikembangkan oleh petugas luar, supervisor dan pimpinan Rayon.

2. Kurangnya training pengembangan diri yang sangat bermanfaat dalam bermanfaat dalam peningkatan produktivitas.

AJB Bumiputera 1912 mempunyai program untuk pengembangan dan latihan untuk para karyawan khususnya untuk para agen dinas luar, namun interval waktu untuk mengadakan latihan tersebut masih sangat sedikit sekali sehingga para agen para agen luar banyak yang mengadakan pendekatan dengan para 
nasabah sesuai dengan kemampuan yang didapat dari latihan terdahulu dan kurang adanya pengembangan diri.

3. Memerlukan modal dengan jumlah besar untuk mengembangkan usaha asuransi.

Untuk mengembangkan usaha asuransi saat ini tidaklah mudah karena dibutuhkan modal yang sangat besar apalagi dimasa krisis ekonomi sehingga untuk mendapatkan dana sebesar itu tidaklah mudah.

4. Prinsip "Customer Always Righ" terkadang mengakibatkan tekanan terhadap tenaga penjual (Personal Selling).

Seringkali para nasabah mempunyai banyak tingkah laku yang bermacammacam sehingga para tenaga penjual seringkali tertekan dengan tingkah mereka tapi ini merupakan resiko tenaga penjual yangg mengakibatkan stress bagi para penjual (personal Selling).

Setelah memperoleh bobot dan rating maka dapat diperoleh skor, dengan cara mengalikan bobot dengan rating,dapat dilihat pada tabel dibawah ini :

\begin{tabular}{|l|l|c|c|c|}
\hline No & \multicolumn{1}{|c|}{ KELEMAHAN } & BOBOT & RATING & SKOR \\
\hline 1 & $\begin{array}{l}\text { Sistem training yang kurang } \\
\text { dikembangkan dari tehnik asuransi } \\
\text { kepada tehnik marketing dan sales bagi } \\
\text { setiap petugas dinas luar, supervisor, } \\
\text { pimpinan rayon sebagai ujung tombak } \\
\text { perusahaan. }\end{array}$ & 4,40 & 1,6 \\
\hline 2 & $\begin{array}{l}\text { Kurangnya training pengembangan } \\
\text { diriyang sangat bermanfaat dalam } \\
\text { peningkatan produktivitas }\end{array}$ & 0,60 & 3 & 1,8 \\
\hline 3 & $\begin{array}{l}\text { Memerlukan Modal dengan jumlah } \\
\text { besar untuk mengembangkan usaha } \\
\text { asuransi }\end{array}$ & 0,80 & 4 & 3,2 \\
\hline 4 & $\begin{array}{l}\text { Prinsip "Customer Always Right “ } \\
\text { terkadang tekanan terhadap tenaga } \\
\text { penjual (Personal selling) }\end{array}$ & 0,75 & 2 & 0,15 \\
\hline \begin{tabular}{l} 
Jumlah \\
\hline
\end{tabular}
\end{tabular}

2. Faktor Eksternal (EFAS)

a. Peluang (Opportunities)

Peluang merupakan merupakan faktor yang berasal dari lingkungan dan menguntungkan bagi perusahaan jika mampu untuk memanfaatkannya. Berdasarkan analisis yang telah dilakukan maka diperoleh beberapa peluang yang dapat dimanfaatkan oleh AJB Bumiputera 1912 yaitu :

1. Sistem Edukatif yang meningkat baik secara langsung maupun tidak langsung tentang peranan asuransi.

AJB Bumiputera 1912 dalam usahanya untuk tetap mempertahankan keberadaanya sebagai " Market Leader" , berusaha terus menerus untuk meningkatkan citra perusahaan dalam pengusaan pasar yang tercermin dalam misi Bumiputera dalam Horizon 2000 akan menjadi perusahaan asuransi jiwa terbesar, terkuat, dan paling menguntungkan dan paling disegani di Indonesia yang berperan serta dalam pembangunan bangsa serta meningkatkan kesejahteraan masyarakat melalui jasa asuransi jiwa.

2. Meningkatnya kesadaran akan pentingnya peranan asuransi bagi organisasi maupun individu, memberi arti yang besar bagi perusahaan asuransi untuk meningkatkan Market Share. 
Saat ini masyarakat sudah banyak yang sadar akan perlindungan baik itu individu maupun organisasi sehingga banyak yang masuk dan bergabung dengan asuransi sehingga bagi perusahaan asuransi akan meningkatkan market sharenya.

3. Populasi yang tinggi

Selama berdiri dari tahun 1912 AJB Bumiputera 1912 sampai sekarang merupakan perusahaan asuransi yang tertua dan mempunyai populasi yang tinggi yang mana sudah melayani lebih kurang 5 jt pemegang polisa yang tersebar diseluruh tanah air Indonesia dibandingkan dengan 44 perusahaan asuransi jiwa di Indonesia.

4. Perkembangan perekonomian yang semakin mantap

Untuk menyongsong era pasar bebas baik itu cepat atau lambat, suka atau tidak suka, rela atau tidak rela ataupun siapa kita , tetap akan menghadapi pasar bebas tersebut, dan untuk mempersiapkan sumber daya manusia yang handal dan didukung oleh tehnologi modern dan cara kerja yang profesional sehingga aJB Bumiputera 1912 tetap berpredikat LEADER MARKET dan memenangkan persaingan dipasar bebas pada awal abad ke XXI diera 2000 ini.

Setelah memperoleh bobot dan rating maka dapat diperoleh skor, dengan cara mengalikan bobot dengan rating,dapat dilihat pada tabel dibawah ini :

\begin{tabular}{|l|l|l|l|l|}
\hline No & \multicolumn{1}{|c|}{ PELUANG } & BOBOT & RATING & SKOR \\
\hline 1 & $\begin{array}{l}\text { Sistem Edukatif yang meningkat baik } \\
\text { secara langsung maupun tidak langsung } \\
\text { tentang peranan asuransi. }\end{array}$ & 0,70 & 4 & 2,8 \\
\hline 2 & $\begin{array}{l}\text { Meningkatnya kesadaran akan } \\
\text { pentingnya peranan asuransi bagi } \\
\text { organisasi maupun individu, memberi } \\
\text { arti yang besar bagi perusahaan } \\
\text { asuransi untuk meningkatkan Market } \\
\text { Share. }\end{array}$ & 4,80 & 4 & 3,2 \\
\hline 3 & $\begin{array}{l}\text { Populasi yang tinggi } \\
\text { semaknbangan perekonomian yang } \\
\text { Jumantan }\end{array}$ & 0,60 & 4 & 2,4 \\
\hline
\end{tabular}

b. Ancaman (Threaths)

Ancaman merupakan faktor yang berasal dari luar perusahaan yang harus diatasi untuk mengurangi dampak yang dapat merugikan perusahaan. Berdasarkan analisis yang telah dilakukan maka diperoleh beberapa ancaman yang dihadapi AJB Bumiputera 1912 dalam mengurangi kerugian yaitu:

1. Pertambahan Market Potensial -meningkatnya persaingan

Sekarang ini banyak perusahaan asuransi yang berdiri sehingga makin banyaknya atau bertambah market potensial sehingga persaingan dapat meningkat dengan cepat . terbukti dengan sudah ada 46 perusahaan asuransi yang berdiri di Indonesia.

2. Meningkatnya Jumlah perusahaan-perusahaan asuransi dengan taktik dan strategi yang agresif dan mantap.

Dengan meningkatnya jumlah perusahaaan asuransi dengan taktik dan strategi yang agresif dan mantap menjadi ancaman bagi AJB Bumiputera 1912 sehingga harus tanggap untuk menghadapi tantangan dan peluang baru dengan mempersiapkan strategi yaitu HORIZON 2000 yang mana intinya ingin tetap berpredikat LEADER MARKET dan memenangkan persaingan dipasar bebas pada awal abad XXI di era 2000. 
3. Sistem pengelolaan pengembangan diri melalui training bagi tenaga pemasar/penjual yang terus meningkat.

Perusahaan AJB Bumuputera 1912 memiliki sekitar 2.900 karyawan dan 23.000 agen tersebar dikantor yang secara strategis tersebar diseluruh Indonesia dan berbagai kegiatan untuk mengembangkan dan meningkatkan sumber daya manusia dengan memberikan latihan-latihan, seminar, dan lain-lain agar karyawan menjadi profesional.

4. Peningkatan Marketing Service

Untuk menghadapi tantangan dan peluang dipasar bebas AJB Bumiputera 1912 telah mempersiapkan sumber daya manusia agar tetap berpredikat LEADER MARKET , upaya ini diharapkan agar dapat memenangkan persaingan dipasar bebas pada abad XXI ditahun 2000 ini.

Setelah memperoleh bobot dan rating maka dapat diperoleh skor, dengan cara mengalikan bobot dengan rating,dapat dilihat pada tabel dibawah ini :

\begin{tabular}{|c|c|c|c|c|}
\hline No & ANCAMAN & BOBOT & RATING & SKOR \\
\hline 1 & $\begin{array}{l}\text { Pertambahan } \quad \text { Market } \\
\text { meningkatnya persaingan }\end{array}$ & 0,30 & 4 & 1,2 \\
\hline 2 & $\begin{array}{l}\text { Meningkatnya Jumlah perusahaan- } \\
\text { perusahaan asuransi dengan taktik dan } \\
\text { strategi yang agresif dan mantap. }\end{array}$ & 0,20 & 4 & 0,8 \\
\hline 3 & $\begin{array}{l}\text { Sistem pengelolaan pengembangan diri } \\
\text { melalui training bagi tenaga } \\
\text { pemasar/penjual yang terus meningkat } \\
\text { Sistem pengelolaan pengembangan diri } \\
\text { melalui training bagi tenaga } \\
\text { pemasar/penjual yang terus meningkat }\end{array}$ & 0,75 & 3 & 2,25 \\
\hline 4 & Peningkatan Marketing Service & 0,65 & 4 & 2,6 \\
\hline & Jumlah & 1,9 & 15 & 6,86 \\
\hline
\end{tabular}

3. Diagram Analisis SWOT

Dari analisis SWOT diatas maka dapat dibuat suatu ringkasan atau rekapitulasi dari perhitungan untuk melihat seberapa besar kekuatan, kelemahan, peluang, dan ancaman yang terjadi pada AJB Bumiputera 1912 Bengkulu.

\begin{tabular}{|l|l|l|l|l|}
\hline \multicolumn{1}{|c|}{ Kekuatan } & \multicolumn{1}{|c|}{ IFAS } & \multicolumn{1}{c|}{ IFAS } & \multicolumn{1}{c|}{ EFAS } & \multicolumn{1}{c|}{ EFAS } \\
\hline $\begin{array}{l}\text { Strategi } \\
\text { pemasaran }\end{array}$ & 19,00 & Weaknesses & \multicolumn{1}{c|}{ Opportunities } & Threats \\
\hline Kuadran & $19,00-6,75=12,25$ & & 10,4 & 6,86 \\
\hline
\end{tabular}

Keterangan dari tabel diatas menjelaskan strategi AJB Bumiputera 1912 Bengkulu. Hasil dari penjumlahan maka kekuatan yang dimiliki adalah 19,00 sedangkan kelemahan adalah 6,75, jadi kuadran internal faktoes yaitu 19,00- 6,75 $=12,25$ artinya kemampuan yang tinggi dari AJB Bumiputera 1912 dalam memanfaatkan kekuatan dan dan mengatasi kelemahan yang terdapat pada internal perusahaan. Peluang yang dimiliki dari strategi tersebut sebesar 10,4 dan ancaman 6,86. Jadi kuadran eksternal faktor yaitu 10,4 - 6,86 = 3,53 artinya kemampuan AJB Bumiputera 1912 dalam memanfaatkan peluang- peluang dan meminimalkan ancaman-ancaman yang dihadapi oleh perusahaan dalam penjualan produk asuransi. Bila kedua nilai tertimbang tersebut dipadukan dalam matrik IE, maka keduanya akan bertemu pada sel I yaitu mendukung strategi agresif. Diagram SWOT akan menujukan pada posisi manakah strategi pemasaran pada AJB Bumiputera 1912 Bengkulu saat ini . Posisi strategi inilah yang akan menentukan letak 
kuadran strategi pemasaran. Kuadran tersebut akan menjadi fundamental analisis strategi kedepan, kuadran- kuadran dapat diamanti secara jelas melalui diagram analisis SWOT berikut ini :

\section{Peluang/Opportunity}

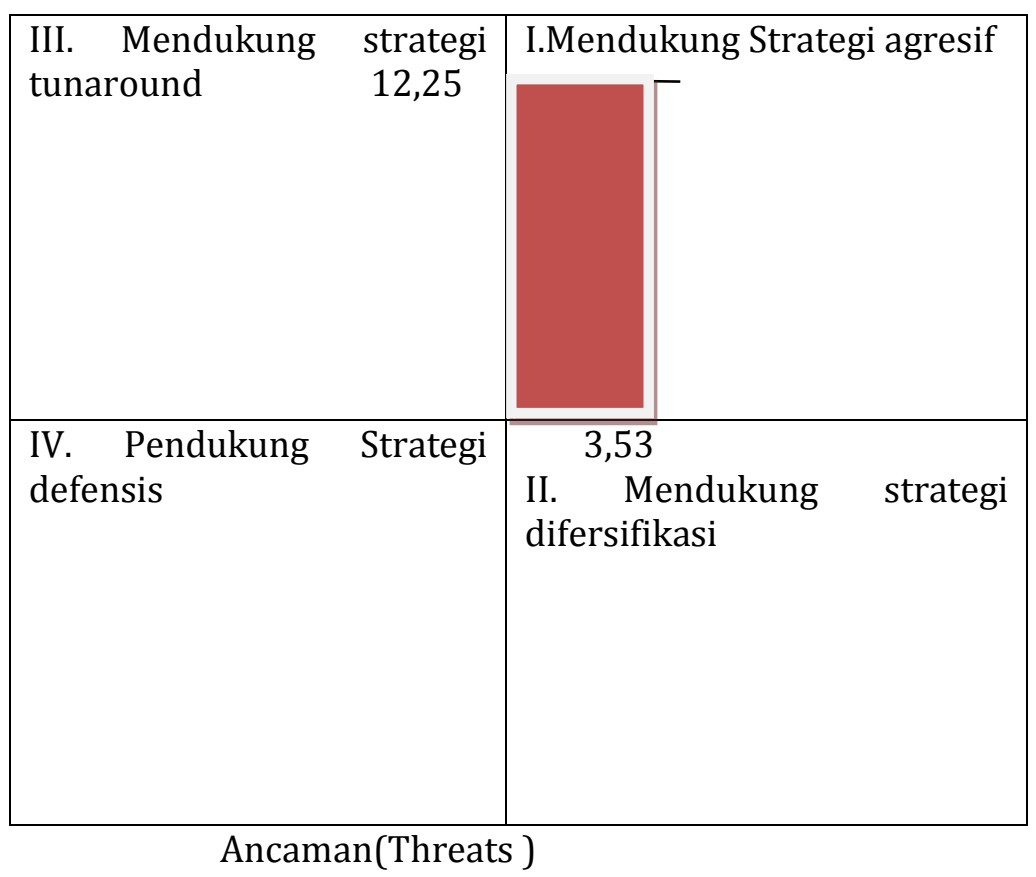

Berdasarkan diagram diatas maka titik berada pada kuadran I yaitu AJB Bumiputera 1912 Bengkulu memiliki peluang dan kekuatan yang besar sehingga dapat memanfaatkan peluang yang ada . strategi yang diterapkan dalam kondisi ini adalah mendukung kebijakan yang agresif. Yaitu dengan cara :

1. Mempertahankan atau meningkatkan pangsa pasar produk saat ini, hal ini dilakukan dengan perencanaan yang matang dan memerlukan promosi yang jauh lebih agresif didukung oleh strategi harga yang terjangkau.

2. Meningkatkan kemampuan SDM , ini dapat dilakukan melalui pemberian pelatihan bagi karyawan, agen debit untuk meningkatkan skill karyawan dan agen debit dalam upaya meningkatkan mekanisme penjualan dan meningkatkan kualitas pelayanan terhadap konsumen.

4. Analisis dengan menggunakan Matrik SWOT.






\begin{tabular}{|c|c|c|}
\hline $\begin{array}{ll}\text { Peluang } & \\
\text { 1. Sistem edukatif } & \text { yang } \\
\text { meningkat maupun secara } & \text { tidak } \\
\text { langsung maupun } & \text { langsung tentang peranan } \\
\text { asuransi. } & \\
\text { 2. } & \text { Meningkatnya kesadaran akan } \\
\text { pentingnya peranan asuransi } & \text { bagi organisasi maupun } \\
\text { individu, memberi arti yang } \\
\text { besar bagi asuransi untuk } \\
\text { meningkatkan marker share. } \\
\text { 3. Populasi yang tinggi } \\
\text { 4. Perkembangan perekonomian } \\
\text { yang semakin mantap. }\end{array}$ & $\begin{array}{ll}\text { Strategi SO } \\
\text { 1. } \\
\text { 2. } \\
\text { 3. } & \text { Merluasan pangsan jaringa distribusi. } \\
\text { SDM. } & \\
\text { 4. } & \text { Memelihara kualitas serta } \\
& \text { mutu pelayanan. } \\
\text { 5. } & \text { Meningkatkan efisiensi } \\
& \text { distribusi. }\end{array}$ & $\begin{array}{l}\text { Strategi WO } \\
\text { 1.Meningkatkan efisiensi produk. } \\
\text { 2.Mengusahakan pengembangan dan } \\
\text { pelatihan SDM. } \\
\text { 3.Mempertahankan } \\
\quad \text { Marketingleader. }\end{array}$ \\
\hline $\begin{array}{l}\text { Ancaman } \\
\text { 1. Pertambahan Market potential } \\
\text { meningkatnya persaingan. } \\
\text { 2. Meningkatnya jumlah } \\
\text { perusahaan asuransi dengan } \\
\text { taktik dan strategi yang agresif } \\
\text { dan mantap. } \\
\text { Sistem Pengelolaan } \\
\text { pengembangan diri melalui } \\
\text { training bagi tenaga } \\
\text { pemasaran bang terus } \\
\text { meningkat. } \\
\text { 4. Peningkatan marketing service }\end{array}$ & $\begin{array}{l}\text { Strategi ST } \\
\text { 1. } \\
\text { Meningkatnya kualitas } \\
\text { kinerja perusahaan yang } \\
\text { lebih baik. } \\
\text { 2. Meningkatan kualitas dan } \\
\text { mutu produk maupun } \\
\text { pelayanan. } \\
\text { 3. } \\
\text { Menetapkan strategi harga. }\end{array}$ & $\begin{array}{l}\text { Strategi WT } \\
\text { 1. Menetapkan strategi bisnis baru } \\
\text { yang lebih efisien dan efektif. } \\
\text { 2. Lebih memperhatikan kualitas } \\
\text { dan mutu pelayanan terhadap } \\
\text { konsumen. }\end{array}$ \\
\hline
\end{tabular}

\section{KESIMPULAN}

1. Dari analisis kuantitatif maupun kualitatif yang dilakukan dilingkungan usaha AJB Bumiputera 1912, baik internal maupun eksternal yang secara keseluruhan merupakan perusahaan terbesar dan sukses dalam bisnis asuransi yang ditunjukkan dengan semakin besar market sharenya serta peningkatan penjualan sepanjang tahun karena didukung oleh kekuatan internal yang cukup baik, dari analisa peluang pasar dengan menggunakan matrik internal dan matrik ekternal yang merupakan pengembangan model General Elektrik , bahwa bisnis perusahaan berada pada posisi stabilitas yang bergerak kearah pertumbuhan dan tujuannya relatif defensif untuk menghindari kehilangan penjualan dan laba.

2. AJB Bumiputera 1912 dalam menghadapi persaingan global harus lebih agresif dalam merebut konsumen untuk mempertahankan market share. Strategi yang bisa diterapkan adalah strategi integrasi horizontal, efisiensi biaya serta memanfaatkan tehnologi tinggi untuk sistem pembayaran dan sistem pemesanan produk asuransi semua ini harus diarahkan untuk kepuasan konsumen.

\section{SARAN}

A. Rencana strategi AJB Bumiputera 1912 dalam jangka pendek:

1. Mempertahankan kualitas produk dengan melakukan pengontrolan secara periodik terhadap produk yang dihasilkan disetiap segmen pasar.

2. Menerapkan kebijakan harga yang bersaing dengan harga pesaing.

3. Secara terus menerus meningkatkan program pengembangan SDM, karena faktor pengembangan SDM merupakan yang terpenting untuk pencapaian rencana strategi.

4. Membina hubungan baik dengan nasabah, misalnya sistem pembayaran yang tepat waktu serta sistem administrasi yang baik.

5. Mengadakan program-program promosi yang dapat meningkatkan penjualan seperti bonus dan lain-lain. 
B. Rencana strategi AJB Bumiputra 1912 dalam jangka panjang:

1. Memantau perkembangan tehnologi, jenis produk, selera konsumen serta persaingan dalam pasar asuransi jiwa.

2. Memahani serta memantau perkembangan, kebutuhan serta kecenderung prilaku konsumen.

3. Terus menerus melakukan riset dan pengembangan produk yang dijual agar tidak ketinggalan pesaing.

4. Terus-menerus melakukan kerjasama yang baik dengan masing-masing Agen Blok dan nasabah sehingga dapat menciptakan sinergi dalam menghadapi pesaing-pesaing yang ada maupun pesaing yang akan muncul.

5. Melakukan ekspansi secara horizontal kewilayah lain yang sedang berkembang didalam memperluas jaringan pemasaran.

\section{DAFTAR PUSTAKA}

Anonym, 2009, Analisis SWOT: Tehnik membedah kasus Bisnis, Jakarta, Erlangga

Rangkuti, Freddy, 2000, Analisis SWOT Tehnik Membedah Kasus bisnis, Jakarta, gramedia.

Tjiptono, Fandy 1997, Strategi Pemasaran, Yogyakarta,Andi Yogyakarta

Kotler Philip ,(1997), Manajemen Pemasaran, Analisis perencanaan, Implementation, dan kontrol, Jakarta, PT. Prenhanllindo.

Irham Fahmi, 2013, Manajemen Risiko : Teori, kasus, dan solusi, Bandung, Alpabeta,

A Junaidy Ganie, 2011, Hukum Asuransi Indonesia, Jakarta, Sinar Grafik.

Herman Darmawi,2001, Manajemen Asuransi, Jakarta, Bumi Aksara.

Totok Budisantoso dan sigit Truiandar, 2009,"Bank dan Lembaga Keuangan lainnya, Jakarta, Salemba empat.

Stanton, William J,1984," Prinsip Pemasaran,Jakarta, Erlangga. 